\title{
Embryonic stem-cell research exempt from ban, NHH is told
}

[WASHINGTON] The US Department of Health and Human Services (DHHS) has issued a legal opinion saying that research on human embryonic stem cells does not fall under the ban on federal funding for human embryo research. The department says this is because such cells do not constitute an 'organism' as described in the legislation.

The decision was due to be announced by Harold Varmus, the director of the National Institutes of Health (NIH), at a meeting of the National Bioethics Advisory Commission on Tuesday (19 January). It marks the next move in a delicate political course the $\mathrm{NIH}$ is trying to steer in the face of an uncertain degree of conservative opposition.

The decision could be codified by a bill likely to be introduced this week by Senator Arlen Specter (Republican, Pennsylvania), chair of the appropriations subcommittee that funds NIH. The bill allows federal support for scientists doing research on stem cells, and may go further, allowing funding for those who derive stem cells from embryos.

Last November, two teams of scientists announced the isolation of the cells, generating hopes for their use in cell and tissue transplants, drug development and basic developmental biology (see Nature 396, 104; 1998). But the uncertain moral status of such cells, given their close link to human embryos, led opponents of human embryo research to urge that federal dollars should not be used to support their use in research.

Bolstered by the DHHS decision, the NIH plans to draw up guidelines for investigators applying for NIH money to do stem-cell research, and to form an oversight group to ensure that applicants follow the guidelines.

"This opinion allows us to proceed carefully and thoughtfully with a line of research that has enormous potential for the treatment of almost every disease and condition," says an NIH official.

But the official added that NIH-funded scientists should wait until the guidelines are in place before launching human stem-cell research. NIH officials hope that, by demonstrating careful guidance of the stem-cell field, they will win public respect for it. They had no such opportunity with human embryo research because of the funding ban.

Varmus "knows the public wants to hear" about the work, says the NIH official, and plans to report publicly on how many researchers are being funded with how many dollars, as well as describing the nature of their work and their findings.

The DHHS decision interprets an existing law that bars federal funding for human

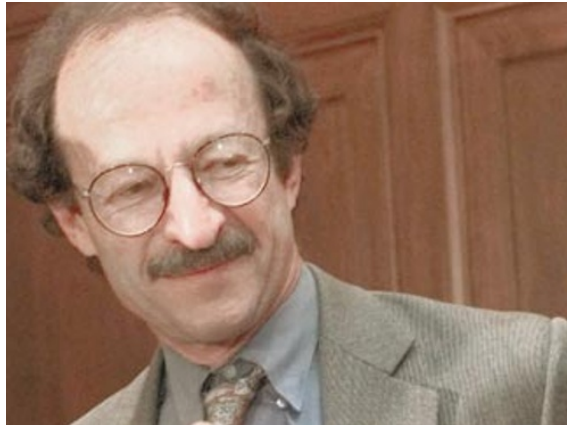

Varmus: planning guidelines for grant applicants.

embryo research in a way that allows support for research on stem cells, but not for their extraction from human embryos. Varmus received the legal opinion from Harriet Rabb, the general counsel at the DHHS, of which NIH is a part.

Rabb noted that the ban on government funding for embryo research describes a human embryo as an "organism" — defined scientifically as an individual constituted to carry out all the functions of its species. Rabb decided that, because stem cells are not organisms, they are not covered by the ban.
The NIH explained the rationale for the decision in the context of the work of James Thomson of the University of Wisconsin, who derived embryonic stem-cell lines using blastocysts left over from fertility treatments.

Thomson derived his cells from the inner cell mass of the blastocyst, which consists of cells that, although retaining the ability to differentiate into many kinds of cells, are unable to give rise to an embryo if implanted in a uterus. So, according to a paraphrase of the DHHS decision provided by NIH, "even if the cells are derived from a human embryo, they are not themselves a human embryo".

Rabb advised, however, that work to derive the cells does fall under the ban, which has been attached by Congress to the annual NIH spending bills since 1995 . She confirmed that the existing law allows, within certain constraints, federal funding for deriving stem cells from tissue of aborted fetuses.

This achievement by John Gearhart, a developmental geneticist at Johns Hopkins University School of Medicine in Baltimore, Maryland, was also announced in November. Gearhart and Thomson were funded by

\section{Insider trading alert over bioscience companies}

[SAN FRANCISCO] Officials of the US Securities and Exchange Commission (SEC) have begun to look closely at bioscience stocks for illegal trading.

Over the past two years, the agency has filed six cases against scientists and consultants suspected of having used inside knowledge about research results to trade stock or to suggest investments to family and friends.

"The agency is increasingly focused on biotechnology as an area where insider trading is a severe problem," says James R. Ferguson, a Chicago securities attorney.

Ferguson says the scientific practice of broadly disseminating confidential research results that could be important to a company's future helps to create the potential for misbehaviour.
Peer reviewers, researchers in clinical trials, journalists and company consultants often have early access to sensitive data.

Such a situation is especially dangerous in young biosciences companies because a positive or negative clinical trial result can have a huge impact on the fate of a company's stock, says Ferguson. And, because scientific developments in the field are more widely reported in the popular press than in other technology areas, they have a greater effect on the stock price.

Questions have been raised, for example, by the frenetic trading in Geron Corp. the day before a report in Science last November that company-funded researchers had been able to grow human embryonic stem cells successfully in the laboratory (see above).

On the day on which the article appeared, the value of Geron stock nearly tripled, although such timing can be purely coincidental. (It is SEC policy to decline to comment on whether investigators are reviewing trading activity in a particular company.)

One industry analyst says that insider trading rules can be especially tricky in the biosciences. "The majority of biotechnology companies don't have revenues or profits, so [investment decisions] revolve around deal rumours, or what you can find out about what's going on experimentally with these drugs," he says.

Some companies, recognizing the potential for problems, issue a summary of clinical results as soon as possible, even before publication in a peer-reviewed journal.

Sally Lehrman 
Geron, a biotechnology company in Menlo Park, California.

An early draft of Specter's bill that was circulating last week declares that "the Secretary [of Health and Human Services] may conduct, support or fund research on, or utilizing, human embryonic stem cells". It also says that federal funding could support the derivation of embryonic stem cells from leftover embryos resulting from in vitro fertilization, providing consent was given by the couple. But it was not clear that this provision would remain in the bill.

Specter indicated at a Senate hearing last week that he intended to try to lift the human embryo research ban as it applies to stem-cell research "at a very early stage" because of the potential for it to deal with serious diseases.

At the hearing, witnesses who implored Specter to exempt stem-cell research from the federal ban included a young man diagnosed with Parkinson's disease at the age of 27 and Doug Melton, chairman of the department of molecular and cellular biology at Harvard University, who has a sevenyear-old son with juvenile diabetes. Both diseases are among those for which stem-cell research is thought to hold most promise.

The biomedical community applauded the DHHS decision. "We are delighted," says William Brinkley, president of the Federation of American Societies for Experimental Biology. "This makes it possible for many more investigators in this country to have access to this technology." Ron Eastman, chief executive officer of Geron, calls it "good news for science and medicine".

But Richard Doerflinger, a spokesman for the National Conference of Catholic Bishops, protested that the decision means that the government will be providing incentives for embryo destruction. "The reward for destroying them is an NIH grant to work on the stem cells thus produced," he said. "It doesn't matter what you did to obtain the stem cells as long as whatever destruction is needed was done without federal funds."

Doerflinger noted that the law governing the use of fetal tissue in federally funded research prohibits carrying out abortions in order to get the tissue. A woman must have chosen an abortion for unrelated reasons,

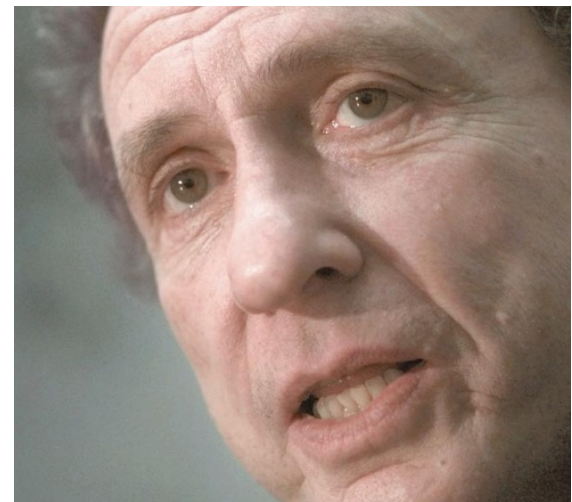

Specter: bill would allow funding for research on human embryonic stem cells.

and have no contact with the researcher. $\mathrm{He}$ says that destroying an embryo to obtain stem cells is morally equivalent to an abortion, and the new policy therefore contravenes the spirit of the existing law on the use of fetal tissue.

Conservative Republicans in Congress could challenge the DHHS decision by broadening the existing ban to explicitly include stem-cell research. MeredithWadman

\section{Space station faces research cuts to cover risk of Russian default}

[WASHINGTON] Space-station managers at the US space agency NASA are braced for a 30 per cent reduction in funds next year for research on the station. The lower-thanexpected allocation is to enable the agency to guard against a possible Russian default on delivering key elements of the station.

Although NASA's budget for the fiscal year 2000 will not be finalized until 1 February, the agency has been told by the White House Office of Management and Budget (OMB) to expect less than half the money it requested to cover such a situation.

OMB's refusal of the full request for contingency planning would result in a "considerable reduction in funding to the [space station] research programmes," says Michael Suffredini, manager of the spacestation payloads office at NASA's Johnson Space Center in Houston.

A memorandum sent by Suffredini to agency research managers on 8 January was leaked last week to NASA Watch, an independent website that tracks space policy issues. As a result of OMB's constraints, the space-station programme faces a $\mathbf{2 0 0}$ million shortfall over the next five years, plus an additional burden of $\$ 70$ million to pay for the development of new technology.

The easiest place to find the money without jeopardizing the space station's tight construction schedule is the research 'utilization' budget, which pays for NASAfunded scientists to develop hardware and experiments for the station. Agency science managers have therefore been asked to draw up plans to scale down their research programmes.

Top priority will be given to maintaining the launch schedule for large 'facility class' instruments, which will be used by many different researchers on the station. Priority will also be given to building hardware for individual experiments that have already passed key design reviews.

The cuts are targeted for the period when the station is being built, with research funding expected to rise again in 2003. NASA officials have promised that past reductions to the research budget would be restored by the time the orbiting laboratory is fully operational in 2004.

Suffredini's memo calls for the number of principal investigators preparing flight experiments to be held "at current levels". NASA had hoped to enlarge the pool of scientists, but the number is now anticipated

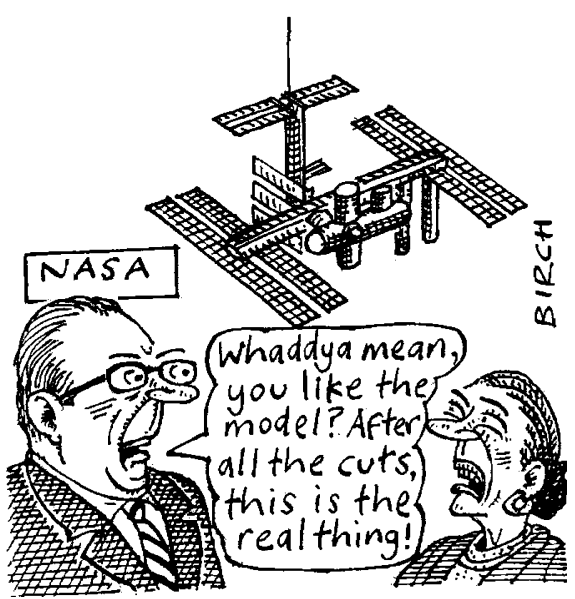

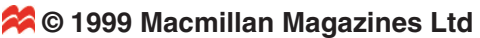

to fall by 30 per cent. Contractors are also likely to be laid off "in selected areas".

The number of scientists involved has been a "highly visible metric with Congress and the research community", wrote Suffredini. With the proposed cuts, "NASA's commitment to research on [the station] appears questionable".

The idea of raiding the station's research budget, even temporarily, to counter problems caused by the partnership with Russia is sure to raise hackles in Congress. Members of the House Science Committee, which oversees NASA's budget, have repeatedly warned the agency not to shortchange science, which has been a leading justification for the project.

Congressional appropriators last year ordered responsibility for the station research budget to be shifted from the human spaceflight office - which operates the space shuttle and is building the station - to the agency's Office of Life and Microgravity Sciences and Applications. But the change has yet to take place.

The reaction on Capitol Hill to a 30 per cent cut, says one congressional source, is likely to be "universally negative". Congress may add more money when it takes up NASA's budget request in the coming year.

Meanwhile, scientists working in the fields of microgravity and life sciences say they are only too accustomed to delays and dwindling budgets for space-station research. When told of the latest funding threat, one NASA-funded scientist quipped: "Ho hum, what else is new?" Tony Reichhardt 